http://journal.uhamka.ac.id/index.php/syukur

\title{
PENGEMBANGAN KESEJAHTERAAN MASYARAKAT MELALUI BUDIDAYA TANAMAN SENGON DI DESA PAMAGERSARI, JASINGA, KABUPATEN BOGOR
}

\author{
Nur Hadiyazid Rachman ${ }^{1}$, Muhammad Fikri Irfani ${ }^{2}$, Lionica Astrida ${ }^{4}$, Lusi Nur Ariyana ${ }^{5}$, Lisa \\ Aprilia ${ }^{6}$, Muhammad Ramdani ${ }^{7}$, Muhamad Hazmi ${ }^{8}$, Muhammad Misbahul Khoir ${ }^{9}$, Nasya \\ Khiyarillah ${ }^{10}$, Nurul Hidayati ${ }^{11}$, Desi Putri Fajar Sari ${ }^{12}$, Syaffia Ulfana ${ }^{13}$, Desiana Husnuzh \\ Zhon $^{14}$
}

\section{${ }^{1}$ Universitas Muhammadiyah Prof. DR. HAMKA}

Email: nur_hadiyazid@uhamka.ac.id ${ }^{1}$

Diterima: 9 Agustus 2018, Direvisi: 13 Agustus 2018, Disetujui: 23 Agustus 2018

\begin{abstract}
ABSTRAK
Rendahnya kesadaran masyarakat dalam membuang sampah pada tempatnya dan bahayanya membuang sampah di sungai merupakan masalah yang paling serius di kalangan masyarakat Desa Pamagersari. Pemukiman masyarakat yang semakin padat dapat mengurangi lahan untuk penanaman pohon, sehingga hal tersebut dapat mengurangi resapan air hujan, sumur yang kering, timbulnya banjir bandang serta menyebabkan pemukiman warga menjadi kering dan gersang. Oleh karena itu kami memiliki program kerja yaitu pengadaan tong sampah dan budidaya tanaman sengon dengan tujuan meningkatkan kesadaran masyarakat terkait masih banyaknya masyarakat yang membuang sampah disungai. Untuk merealisasikan tujuan program kerja kami, kami memberikan tempat pembuangan sampah disekitar desa yang berfungsi juga sebagai sarana penghijauan lingkungan agar lingkungan tidak kering, tidak gersang dan tetap memiliki resapan air. Air yang meresap ke dalam tanah dapat menambah debit air yang masuk ke dalam sumber bertambah terutama untuk daerah yang tanahnya tidak mendukung sebagai tempat pembuatan sumur. Selain untuk peresapan air, hasil dari penanaman pohon tersebut juga dapat dimanfaat masyarakat sebagai sumber perekonomian.
\end{abstract}

Kata Kunci: Kesejahteraan Masyarakat, Peningkatan Kebersihan, Penghijauan Lingkungan

\section{ABSTRACT}

The low awareness of the community in disposing of garbage in its place and the dangers of throwing garbage in the river is the most serious problem among the Pamagersari Village community. As well as increasingly crowded community settlements can reduce land for tree planting, so that it can reduce rainwater absorption, dry wells, flash floods and cause residents to become dry and arid. Therefore we have a work program namely Procurement of Sengon Trash and Plant Cultivation with the aim of increasing public awareness about the many people who throw garbage in the river by providing garbage disposal around the village and for greening the environment so that the environment is not dry and arid and also for water infiltration. Water that permeates can increase the flow of water entering the source, especially for areas where the land does not support the well. In addition to water infiltration, the results of planting these trees can also be benefited by the community for the economy.

Keywords: Community Welfare, Improved Hygiene, Greening of The Environment 
http://journal.uhamka.ac.id/index.php/syukur

\section{PENDAHULUAN}

Sengon (Albizia chinensis) adalah sejenis pohon anggota suku Fabaceae. Pohon peneduh dan penghasil kayu ini tersebar secara alami di India, Asia Tenggara, Cina Selatan, dan Indonesia (http://id.wikipedia.org/wiki/Sengon, diakses pada tanggal 8 September 2018).

Menurut Corryanti dan Novitasari (2015), sengon dapat tumbuh di atas ragam jenis tanah, mulai di tanah kering, lembab bahkan tanah yang mengandung garam dan asam. Pada pengamatan lain menginformasikan, tanaman sengon dapat tumbuh dan berkembang baik di tanah-tanah regosol, latosol atau aluvial dengan tekstur lempung berdebu atau lempung berpasir dengan tingkat keasaman tanah $(\mathrm{pH})$ pada kisaran 6 sampai dengan 7 . Sengon termasuk tanaman tropis dengan suhu yang cocok untuk pertumbuhannya pada kisaran $18-27^{\circ} \mathrm{C}$ dengan kelembaban sekitar 50\% sampai dengan $75 \%$.

Lebih lanjut menurut Corryanti dan Novitasari (2015), ketinggian tempat yang optimal untuk tanaman sengon yaitu antara 0-800 $\mathrm{m}$ dari permukaan laut. Walaupun demikian, tanaman sengon dapat tumbuh sampai ketinggian $1.500 \mathrm{~m}$ di atas permukaan laut. Di habitat alamnya, sengon tumbuh pada ketinggian hingga $1.600 \mathrm{~m}$ sampai 3.300 $\mathrm{m}$ dari permukaan laut. Tanaman sengon dapat tumbuh pada beragam curah hujan antara $1.500-4.500 \mathrm{~mm} / \mathrm{tahun}$. Namun, curah hujan terbaik untuk tanaman sengon adalah antara $2.000-2.700 \mathrm{~mm} /$ tahun. Curah hujan ini terjadi di kawasan yang memiliki masa hujan merata sepanjang tahun dengan bulan kering maksimal empat bulan.

Semua bagian pada tanaman ini memiliki manfaat dan kegunaan bagi manusia dari daun hingga akar. Nilai ekonomis yang dapat diperoleh dari Pohon Sengon adalah jenis pohon kayu cepat tumbuh (fast growing species), pengelolaan relatif mudah, sifat kayunya termasuk kelas kuat dan permintaan pasar yang terus meningkat (Nugroho dan Salamah, 2015), sedangkan secara ekologis Sengon dapat meningkatkan kualitas lingkungan seperti meningkatkan kesuburan tanah dan memperbaiki tata air (Suharti, 2008).

Tanaman sengon banyak ditemukan pada lahan yang dikelola oleh negara maupun masyarakat. Desa Pamagersari yang terletak di bagian Timur Kecamatan Jasinga, Kabupaten Bogor merupakan salah satu desa yang memiliki pabrik pengelolaan sengon. Pohon sengon yang diperoleh oleh pabrik berasal dari hutan milik negara dan hutan milik masyarakat.

Berdasarkan hasil survei tidak kurang 20 pabrik berdiri di sekitar Desa Pamagersari (Tim Survei Kelompok 12 PKM FEB-UHAMKA, 2018). Hasil wawancara Tim Survei Kelompok 12 PKM FEB-UHAMKA dengan pemilik pabrik menemukan fakta bahwa penjualan kayu sengon dalam sehari bisa mencapai 5 sampai dengan $10 \mathrm{~m}^{3}$ atau pada pemilik pabrik yang lain bisa mencapai 1000 batang kayu kaso ukuran 4 x $6 \mathrm{~cm}$. Jika 
http://journal.uhamka.ac.id/index.php/syukur

asumsi yang digunakan menggunakan luasan tabung, maka pohon sengon dengan tinggi 7 meter yang memiliki diameter penampang $20 \mathrm{~cm}$ (0,2 meter) akan memiliki kubikasi sebesar $=22 / 7 \times 0,1 \times 0,1 \times 7=0,22 \mathrm{~m}^{3}$. Hal ini menunjukkan bahwa jumlah pohon yang dibutuhkan dalam pemenuhan kebutuhan konsumen kurang lebih sebesar 25 sampai 50 pohon perhari.

Tingginya penjualan kayu sengon tidak terlepas dari keuntungan yang menggiurkan pada bisnis ini. Wawancara PKM Kelompok 12 FEB-UHAMKA dengan pemilik pabrik menunjukkan hasil bahwa harga beli pohon sengon sebesar Rp 300.000/ $\mathrm{m}^{3}$. Sementara harga jual kayu sengon seperti yang dikutip dari situs https://www.hargabulanini.com/ harga-kayu-sengon-terbaru/ (diakses tanggal 8 September 2018), seperti yang tertera pada tabel 1. di bawah ini.

Tabel 1. Harga Jual Kayu Sengon $/ \mathrm{m}^{3}$

\begin{tabular}{|c|c|c|}
\hline Panjang & Diameter & Harga \\
\hline $103 \mathrm{~cm}$ & $20-24 \mathrm{~cm}$ & 800.000 \\
\hline & $25-29 \mathrm{~cm}$ & 850.000 \\
\hline & $20-39 \mathrm{~cm}$ & 900.000 \\
\hline & $40-49 \mathrm{~cm}$ & 950.000 \\
\hline & $50-59 \mathrm{~cm}$ & 1.000 .0000 \\
\hline $130 \mathrm{~cm}$ & $15-18 \mathrm{~cm}$ & 750.000 \\
\hline & $19-24 \mathrm{~cm}$ & 800.000 \\
\hline & $25-29 \mathrm{~cm}$ & 850.000 \\
\hline & $30-39 \mathrm{~cm}$ & 900.000 \\
\hline & $40-49 \mathrm{~cm}$ & 950.000 \\
\hline & $50-59 \mathrm{~cm}$ & 1.000 .000 \\
\hline $200 \mathrm{~cm}$ & $20-24 \mathrm{~cm}$ & 820.000 \\
\hline & $25-29 \mathrm{~cm}$ & 820.000 \\
\hline & $20-39 \mathrm{~cm}$ & 910.000 \\
\hline & $40-49 \mathrm{~cm}$ & 985.000 \\
\hline $300 \mathrm{~cm}$ & $50-59 \mathrm{~cm}$ & 1.010 .000 \\
\hline & $25-29 \mathrm{~cm}$ & 840.000 \\
\hline & $20-39 \mathrm{~cm}$ & 960.000 \\
\hline & $40-49 \mathrm{~cm}$ & 1.050 .000 \\
\hline
\end{tabular}

Sumber: https://www.hargabulanini.com/harga-kayu-sengon-terbaru/

Akibat tingginya nilai ekonomis pohon sengon menjadikan pelaku bisnisnya berlomba-lomba untuk melakukan penebangan tanpa ada program penghijauan yang optimal. Hal tersebut berdampak negatif bagi kondisi lingkungan. Hutan-hutan di sekitar Desa Pamagersari menjadi gundul, baik itu milik rakyat ataupun yang dikelola oleh negara, hal ini dibuktikan dengan terjadinya banjir bandang terbesar yang dialami oleh penduduk Desa Pamagersari pada tahun 2017 (sumber: wawancara dengan Bapak RT02 RW01 Desa Pamagersari).

Desa Pamagersari merupakan desa yang terletak di bagian timur Kecamatan Jasinga dan berbatasan dengan empat desa yang berada di kecamatan yang sama. Di sebelah utara, Desa Pamagersari berbatasan dengan Desa Setu. di bagian selatan, desa ini berbatasan dengan dua desa, yaitu Desa Jugalajaya dan Desa Pangradin. Di sebelah timur, Desa Pamagersari berbatasan dengan Desa Sipak. Di sebelah barat, Desa Pamagersari 
berbatasan dengan Desa Jasinga. Desa Pamagersari berada dalam koordinat 106.468353 Bujur Timur dan -6.480204 Lintang Selatan. Desa ini memiliki luas wilayah sekitar 314 Hektar. Sebagian besar warga desa ini bekerja sebagai buruh dan pedagang.

Desa Pamagersari dilalui sungai di sepanjang wilayahnya. Debit air sungai pada musim kemarau akan sangat kecil tetapi pada musim penghujan dapat berubah menjadi sangat banyak bahkan bisa mengakibatkan banjir. Masyarakat masih menggunakan sungai untuk aktivitas sehari-hari seperti mandi dan mencuci. Namun sungai yang merupakan tempat kegiatan sehari-hari dan sebagai sumber air yang digunakan masyarakat sangat tidak layak digunakan karena banyaknya sampah dipinggiran sungai yang dapat menyebabkan air sungai tercemar. Banyak masyarakat yang membuang sampah disungai karena tidak adanya tempat pembuangan akhir serta kurangnya kesadaran masyarakat dalam membuang sampah pada tempatnya. Sampah yang didominasi plastik menumpuk dan hampir memenuhi seluruh aliran sungai. Sungai itu berwarna hitam pekat dan menimbulkan bau tak sedap. Air sumur yang berada didekat sungai keruh dan bau karena banyak timbunan sampah disekitar sungai.

Maka untuk membantu masyarakat sadar terhadap lingkungan sekaligus membantu masyarakat mendapatkan alternatif lapangan pekerjaan perlu untuk dibuatkan program kerja yang jelas dan berkelanjutan. Kami harapkan program kerja yang kami lakukan berupa penanaman di Desa Pamegarsari dapat menjadi solusi nyata bagi permasalahan warga di desa tersebut.

\section{MASALAH}

Permasalahan yang dialami mitra terdiri dari, yaitu: (1) Hulu; penebangan hutan secara masif karena nilai ekonomis dari kayu sengon dan (2) Hilir; perilaku masyarakat Desa yang membuang sampah ke sungai sehingga sungai menjadi dangkal dan alirannya terhambat.

\section{METODE}

Metode pelaksanaan pemberdayaan masyarakat terbagi dalam dua tahapan, yaitu:

1. Mengumpulkan data yang berkaitan dengan: situasi, permasalahan, dan potensi yang dimiliki oleh mitra (Desa Pamagersari RW 01). Pengumpulan data dilakukan dengan cara, antara lain yaitu:

1) Metode observasi (pengamatan).

Pengamatan adalah alat pengumpulan data yang dilakukan dengan cara mengamati dan mencatat secara sistematik gejala-gejala yang ada di Desa Pamagersari. Data yang diperlukan dalam metode pengamatan ini yaitu mengamati secara langsung dilokasi,. 
2) Metode Wawancara

Suatu metode pengumpulan data yang dilakukan melalui tanya jawab secara langsung dengan sumber data. Dalam wawancara secara mendalam ini dilakukan oleh penulis terhadap Ketua RW 01 dan Ketua RT di RW 01 Desa Pamagersari, Wawancara ini bertujuan untuk memperoleh informasi yang ada relevansinya dengan pokok persoalan yang ada di Desa Pamagersari.

Wawancara juga dilakukan kepada pemilik pabrik untuk mengetahui potensi perekonomian dari kayu sengon (sebagai solusi atas permasalahan mitra) dengan menyebarkan kuesioner kepada pabrik-pabrik pengolah kayu sengon di Kecamatan Jasinga.

3) Metode Dokumentasi

Pengumpulan data dengan mengumpulkan catatan-catatan dan data yang sudah dimiliki oleh narasumber (Ketua RW 01 dan Ketua RT di RW 01 Desa Pamagersari).

2. Melaksanakan program pemberdayaan kepada masyarakat (solusi yang ditawarkan) berdasarkan hasil analisis data terhadap situasi, permasalahan, dan potensi RW 01 Desa Pamagersari.

\section{PEMBAHASAN}

\section{Hasil dan Luaran yang dicapai}

Dari permasalahan yang telah dijelskan di atas, maka solusi yang kami tawarkan diantaranya:

1. Penyuluhan kebersihan dengan memberikan penyuluhan kebersihan kepada masyarakat RW 01 Desa Pamagersari untuk tidak membuang sampah ke sungai.

2. Workshop dan pelatihan budidaya tanaman sengon.

Hasil kegiatan pengabdian kepada masyarakat pada RW01 Desa Pamagersari, Kecamatan Jasinga, Kabupaten Bogor sebagai berikut:

1. Edukasi kebersihan lingkungan dan sungai

Sosialisasi kebersihan lingkungan dan sungai merupakan program kerja yang berhasil dilaksanakan dengan mengikutsertakan para sesepuh dan karang taruna di RW 01 Desa Pamagersari. Harapan dari kegiatan ini adalah munculnya kesadaran secara kolektif dari masyarakat untuk menjaga kebersihan lingkungan dan sungai. 
http://journal.uhamka.ac.id/index.php/syukur
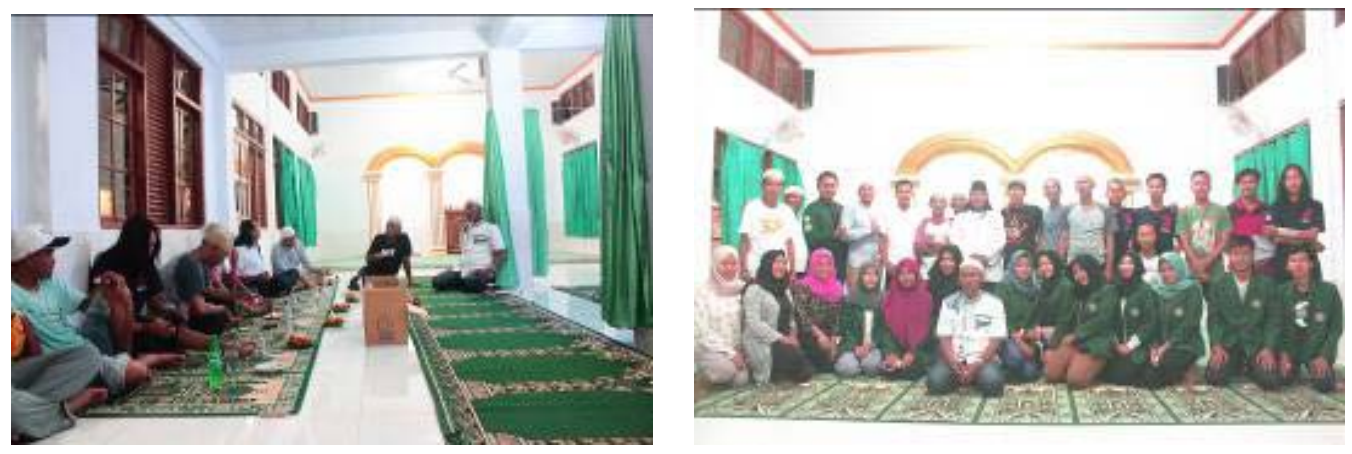

Gambar 1. Edukasi Kebersihan Lingkungan dan Sungai

2. Pengadaan tong sampah

Pengadaan tong sampah merupakan program kerja yang berhasil dilaksanakan bekerjasama dengan pemuda karang taruna di RW 01 Desa Pamagersari. Peletakan tong-tong sampah di tempat strategis diharapkan dapat mengurangi kebiasaan warga desa yang membuang sampah ke sungai.
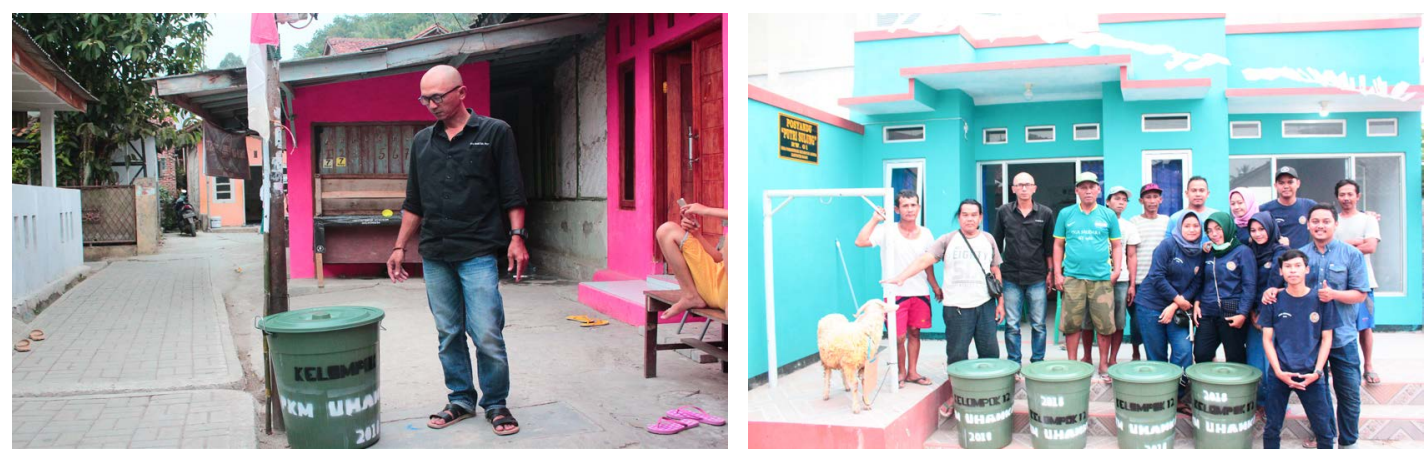

Gambar 2. Pengadaan Tong Sampah Bersama Masyarakat

3. Edukasi penanaman bibit pohon sengon

Edukasi penanaman bibit sengon merupakan program kerja yang berhasil dilaksanakan. Bekerjasama dengan Bapak RT 02 dan pemuda karang taruna Desa Pamagersari, kegiatan ini mendapatkan animo dan atensi yang luar biasa. Sebagai desa dengan latar belakang pekerjaan warganya yang tidak tetap, program ini diharapkan dapat membantu masyarakat Desa Pamagersari menjadi salah satu alternatif mengurangi pengangguran. 
http://journal.uhamka.ac.id/index.php/syukur
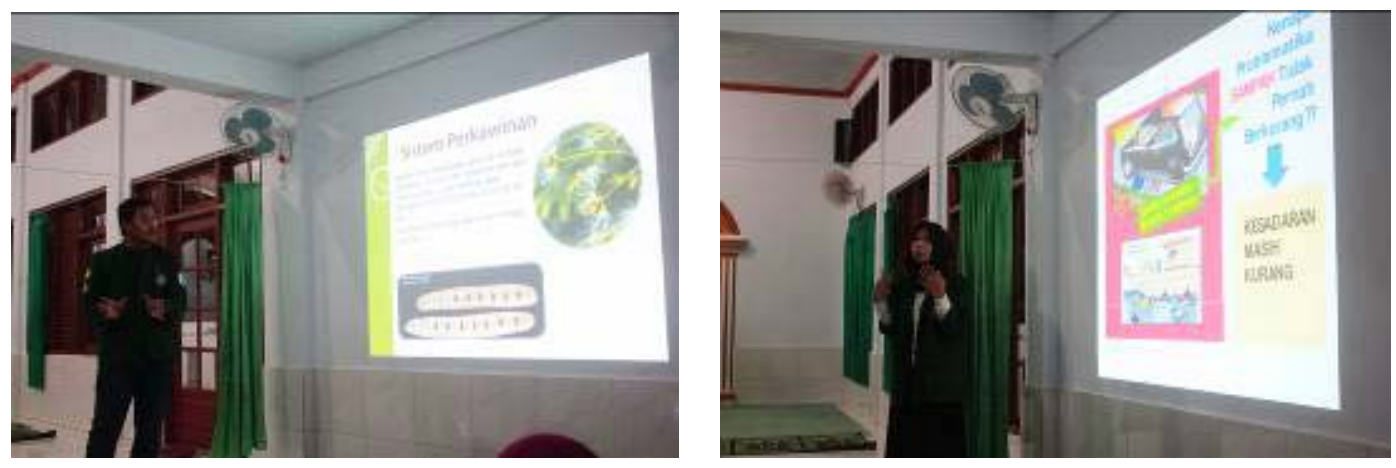

Gambar 3. Edukasi Budidaya Tanaman Sengon

\section{Penanaman bibit pohon sengon}

Selain program tersebut di atas, kami juga melaksanakan program penanaman bibit pohon sengon. Program ini diharapkan dapat mengatasi permasalahan kurangnya penghijauan dan kurangnya resapan air di Desa Pamagersari. Selain untuk penghijauan dan resapan air, pohon sengon ini juga dapat dimanfaatkan masyarakat untuk menciptakan sebuah lapangan kerja baru untuk menambah pendapatan yaitu dengan membudidayakan pohon sengon ini dan jika sudah besar, kayu dari pohon sengon ini dapat dimanfaatkan hasilnya oleh masyarakat sekitar.

Tahapan yang dilakukan sebelum dilakukannya penanaman bibit sengon, yaitu:

1) Melakukan Ekstraksi biji atau pengeluaran biji dari polong dapat dilakukan setelah biji dikumpulkan. Pada umumnya polong akan pecah jika sudah masak, atau kering.

2) Melakukan pengecambahan benih

Media tabur yang dipergunakan adalah tanah pasir dengan perbandingan 1:1.

Adapun tahapan kegiatan yang harus dilakukan adalah sebagai berikut:

a. Media tabur diayak terlebih dahulu sampai halus dengan tujuan untuk memudahkan proses perkecambahan.

b. Media tanah dan pasir distrerilkan dari jamur dengan cara dipanggang diatas seng dengan tungku pemanas.

c. Biji sebelum ditabur direndam air panas $\left( \pm 80^{\circ} \mathrm{C}\right)$ dan dibiarkan sampai dingin selama 24 jam.

d. Selanjutnya, benih yang sudah direndam, dirtiriskan; bak kecambah yang telah berisi media pasir-tanah 1:1 di siram terlebih dahulu dengan air distilasi yang selanjutnya ditaburi benih.

e. Bak kecambah yang sudah ditaburi benih, kemudian ditaburi pasir tipistipis sampai semua benih tertutu, kemudian dilakukan penyemprotan dengan sprayer halus mengunakan air terdistilasi dan ditutup menggunakan 
http://journal.uhamka.ac.id/index.php/syukur

plastik penutup untuk menjaga kelembapan.

f. Kecambah akan muncul kotiledonnya setelah 1 sampai dengan 2 minggu kecambah yang kemudian dipindahkan ke media di dalam kantong plastik di bedeng semai.

g. Pemeliharaan kecambah di bak kecambah adalah dengan menyiram setiap pagi dan pembersihan gulma yang tumbuh di atas media perlu dilakukan secara rutin.

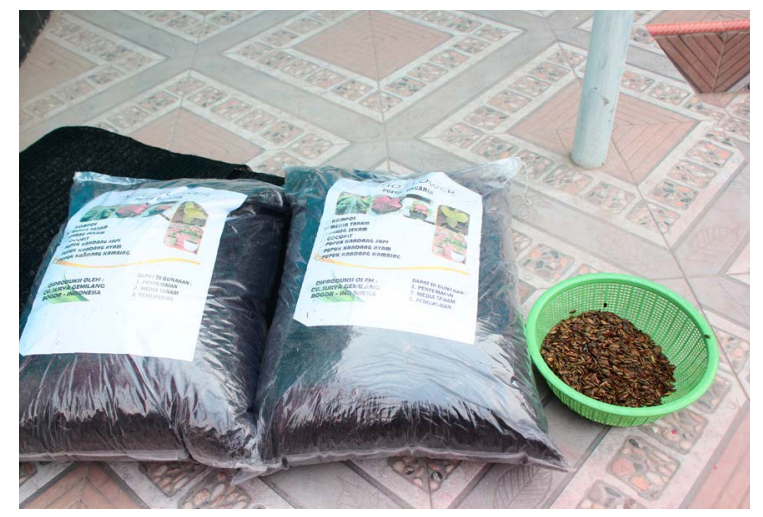

Gambar 4. Biji/Benih Sengon dan Pupuk yang digunakan

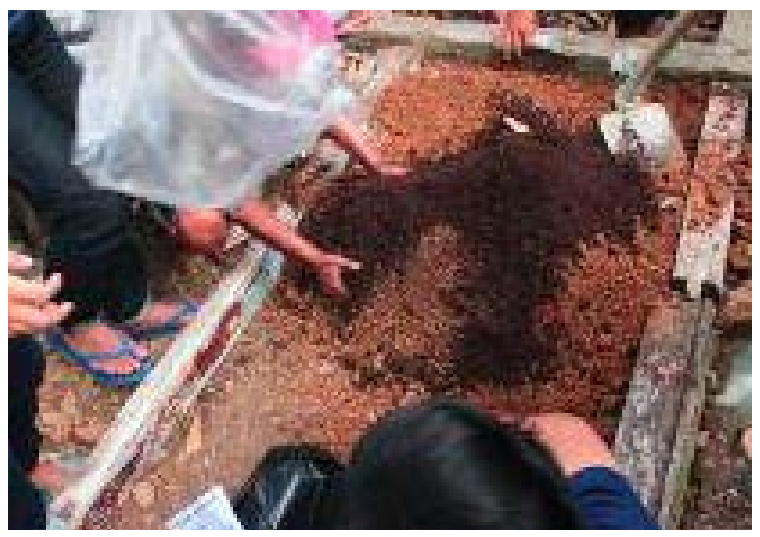

Gambar 5. Pencampuran Media Tanah dengan Pupuk

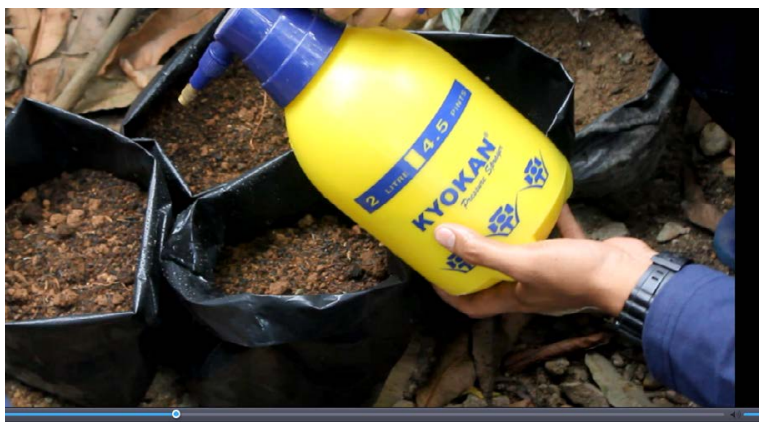

Gambar 6. Penyemprotan Media yang Telah Ditanam Biji Sengon 
http://journal.uhamka.ac.id/index.php/syukur
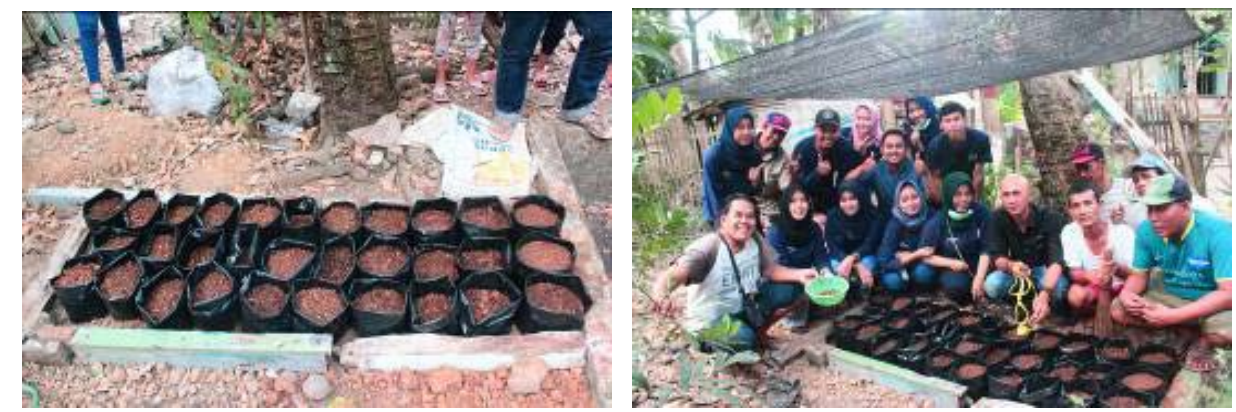

Gambar 7. Bibit yang Telah Dimasukan Dalam Media Tanah

\section{KESIMPULAN}

Pelaksanaan kegiatan Pengabdian Kepada Masyarakat di RW 01 Desa Pamagersari meliputi kegiatan:

1. Pengadaan tong sampah serta edukasi kebersihan lingkungan dan sungai diharapkan mampu merubah perilaku masyarakat untuk tidak membuang sampah ke sungai.

2. Edukasi dan penanaman bibit sengon diharapkan mampu memberikan solusi terhadap permasalahan antara lain yaitu: (a) Penggundulan hutan, (b) Banjir pada saat musim hujan, (c) Kekurangan air bersih pada saat musim kemarau, dan (d) Pengangguran.

\section{SARAN}

Saran penulis terhadap permasalahan yang terjadi pada RW 01 Desa Pamagersari sebagai berikut:

1. Mengendalikan penebangan liar yang terjadi baik di hutan milik rakyat maupun hutan milik negara.

2. Menanam kembali lahan-lahan yang kritis dengan tanaman yang memiliki nilai ekonomi yang tinggi seperti pohon sengon.

3. Membuat pusat-pusat penanaman bibit pohon sengon di seluruh wilayah Kecamatan Jasinga.

\section{DAFTAR PUSTAKA}

Baskorowati, Dr. Liliana. 2014. Budidaya Sengon Unggul Untuk Pengembangan Hutan Rakyat. Jakarta. PT Penerbit IPB Press

Corryanti dan D. Novitasari. 2015. Sengon dan Penyakit Karat Tumor. Cepu. Puslitbang Perum Perhutani.

http://id.wikipedia.org/wiki/Sengon, diakses pada tanggal 8 September 2018

Nugroho, T.A. dan Z. Salamah. 2015. Pengaruh Lama Perendaman dan Konsentrasi Biji Sengon (Paraserianthes falcataria L.). JUPEMASI-PBIO, Vol. 9 No. 3

Suharti. 2008. Aplikasi Inokulum EM-4 dan Pengaruhnya Terhadap Pertumbuhan Bibit 
http://journal.uhamka.ac.id/index.php/syukur

Sengon (Paraserianthes falcataria (L.). Jurnal Penelitian Hutan dan Konservasi Alam. Vol. V no. 1. 